\title{
Chondroitin Sulfate and Hyaluronic Acid Perfusion for Interstitial Cystitis/Bladder Pain Syndrome A Systematic Review and Meta-Analysis
}

\author{
Xiang Xiao, ${ }^{1, \uparrow}$ Huan Deng, ${ }^{1, \uparrow}$ Mumba Mulutula Chilufya, ${ }^{1}$ Yizhen Lv, ${ }^{1}$ \\ Yan Zhao, ${ }^{1}$ Jiaxin Liu, ${ }^{1}$ Ziwei Guo, ${ }^{1}$ Lichun Qiao, ${ }^{1}$ Jing Han, ${ }^{1,}$ \\ Dong Wang, ${ }^{2, *}$ Chengjuan $\mathbf{Q u}^{3}$ \\ 1. School of Public Health, Xi'an Jiaotong University, Xi'an 710061, Shaanxi, P. R. China \\ 2. Key Laboratory of Biomedical Engineering of Hainan Province, School of Biomedical Engineering, Hainan University, Haikou 570228, \\ Hainan, P. R. China \\ 3. Department of Odontology, Umeå University, Umeå, 90185, Sweden \\ 9: These authors contributed equally to this work. \\ *: All corresponding should be sent to Drs. Jing Han and Dong Wang. \\ Authors' Contact: Xiang Xiao, E-mail: m18064304317@163.com, ORCID: 0000-0003-4053-1706; Huan Deng, E-mail: 957336248@qq.com, \\ ORCID: 0000-0002-4298-3581; Mumba Mulutula Chilufya, E-mail: mumba.mmc@gmail.com, ORCID: 0000-0001-7812-022X; Yizhen Lv, E-mail: \\ yizhenlv61@163.com, ORCID: 0000-0002-8376-0747; Yan Zhao, E-mail: 2533218374@qq.com, ORCID: 0000-0002-7116-8631; Jiaxin Liu, \\ E-mail: lix17809289471@163.com, ORCID: 0000-0001-9335-6679; Ziwei Guo, E-mail: 1048116303@qq.com, ORCID: 0000-0002-8371-840X; \\ Lichun Qiao, E-mail: 978402409@qq.com, ORCID: 0000-0002-6739-0846; Jing Han, E-mail: bbbishop@126.com, ORCID: \\ 0000-0003-1460-0114; Dong Wang, E-mail: wangdong@hainanu.edu.cn, ORCID: 0000-0002-8209-210X; Chengjuan Qu, E-mail: \\ chengjuan.qu@umu.se, ORCID: 0000-0002-1710-7715. \\ Funding: This work was funded by the National Natural Science Foundation of China (81872567). \\ DOI: https://doi.org/10.15354/si.21.re266. \\ The authors declare no competing interest.
}

Currently, no suitable delivery methods are available for the drugs to interstitial cystitis/ bladder pain syndrome (IC/BPS). Herein we systematically evaluated the therapeutic effects of intravesical infusion of hyaluronic acid (HA) and chondroitin sulfate (CS) in patients with IC/BPS. This study includes randomized controlled trials (RCT) and self-controlled studies of IC/BPS patients treated with HA, CS, or both. English databases like PubMed, Cochrane Library, Embase, and Medline were searched until up to January 31, 2021. Information was extracted based on the inclusion and exclusion criteria, and then meta-analysis was performed. Sixteen studies including 491 patients were included and analyzed. The responsive rate of treatment was $91.24 \%$. In 3 RCTs, the analogue scale (VAS) for pain on fix-effect model was [mean difference, MD $-0.57(95 \% \mathrm{Cl},-1.55,-0.41)]$. A significant improvement on random-effect model was [MD -2.78 $(95 \% \mathrm{Cl},-\mathbf{3 . 4 8},-\mathbf{2 . 0 7})$ ] in 13 self-controlled studies. Outcomes on O'Leary-Sant Interstitial Cystitis Symptom Index, Problem Index, frequency, urgency, and bladder capacity were also significantly improved. Subgroup analysis showed significant difference between HA, CS, and the combination, and the perfusion of HA was more effective $(Z=29.97, P<0.01)$. Also, different follow-up times after last treatment showed significant difference $(Z=7.69, P<0.01)$. It can be beneficial for IC/BPS patients who have not responded to conventional treatments.

Keywords: Interstitial cystitis; Bladder pain syndrome; Chondroitin sulfate; Hyaluronic acid; Meta-analysis

Science Insights, 2021 December 02; Vol. 39, No. 4, pp.361-373.

(c) 2021 Insights Publisher. All rights reserved.

(i) Creative Commons Non Commercial CC BY-NC: This article is distributed under the terms of the Creative Commons Attribution-NonCommercial 4.0 License which permits non-commercial use, reproduction and distribution of the work without further permission provided the original work is attributed by the Insights Publisher. 


\section{Introduction}

A $\mathrm{S}$ a complex and dynamic macromolecular network in the cellular microenvironment, the extracellular matrix (ECM) plays an increasingly important role in cell biology, including the regulation of cell behavior, tissue development, function and repair through direct or indirect manipulation(1, 2). Glycosaminoglycans (GAGs), as an important component of ECM, play a vital role in cell growth, angiogenesis, tumor metastasis, proliferation and differentiation (3-5). GAGs are classified into four major groups based on their structure and function: hyaluronic acid (HA), chondroitin sulfate (CS), heparin sulfate, and keratin sulfate (6). HA is a widely used polymer that is mostly found in connective, epithelial, and neural tissues. It is involved in cell proliferation and migration as one of the main components of ECM $(6,7)$. CS is also widely found in ECM and has special biological roles in regulation of cell behavior and fate (such as proliferation and differentiation) (8). In the bladder urothelium, for example, HA and CS are important components of the GAG layer and constitute a protective barrier.

Interstitial cystitis/ bladder pain syndrome (IC/BPS) is a chronic bladder disease, which usually presents as dysuria, pelvic pain, dyspareunia, urinary urgency, and frequency (9). The disease harms many aspects of the patients' lives, and most of which are female. An estimated 1.3 million people in United States suffer from BPS, including 1.2 million women (10). The age of onset of IC is usually between 39 and 73 years, with an average age of 63 years (11). At present, although great achievements have been made in the treatment of IC/BPS, there is no universally accepted treatment method, and the existing treatment methods mainly include diet therapy, behavior adjustment training (BAT), oral medication, intravesical perfusion, and surgical intervention (12).

At present, the etiology of IC/BPS is still unknown, while some evidence suggests that pain syndromes are associated with alterations in the urothelial epithelial layer. For example, changes in the urothelial barrier may cause water, urea, and other toxic substances to enter the basic tissues (nerve and/or muscle layers), resulting in symptoms of urgency, frequent urination, and pain during bladder filling and urination (13). Previous studies have shown that the disease might be related to defects in the mucin glycosaminoglycan (GAG) layer of the bladder urothelium (7). Therefore, according to the physiological function of the GAGs, early repair of the GAGs can improve the integrity and function of the bladder, thereby avoiding subsequent chronic bladder inflammation. As relevant components of the GAG layer, HA and CS treatments have been reported to be effective in the treatment of IC/BPS in many studies $(14,15)$.

However, there is still a lack of a unified basis for the efficiency of different drugs. At the same time, some contrary results showed that HA and CS are not better than placebo (16). To further investigate, we performed this systematic review and meta-analysis to evaluate the efficiency of intravesical HA and CS perfusion in patients with IC/BPS by using recent pieces of evidence.

\section{Materials and Methods Protocol Development}

According the instructions of Preferred Reporting Items for
Systematic Review and Meta-Analysis (PRISMA) guidelines, the study protocol was designed and registered in the International Prospective Register of Systematic Reviews database (PROSPERO) before the beginning of the study, with the identification number is CRD42021238485. The detailed information about PICO (population, intervention, comparison, and outcome) questions are as follows:

\section{Search Strategy}

Articles included in the review were obtained by searching PubMed, Medline, Cochrane Library, and Embase databases, from the time of database establishment up until January 31, 2021. The search keywords were interstitial cystitis or bladder pain syndrome or painful bladder syndrome and hyaluronic acid or chondroitin sulfate. The search strategy in the PubMed database are presented in Table 1, other databases have the same search strategy.

\section{Selection Criteria and Data Extraction}

Two reviewers screened the titles and abstracts independently. The full paper was obtained if any of the reviewers considered the reference potentially relevant. The search results were included according to the following criteria. Inclusion criteria: (i) intravesical HA and/or CS perfusion were performed in human subjects with IC/BPS; (ii) articles were reported in English. Exclusion criteria: (i) non-full-text articles; (ii) studies using animals or cell lines; (iii) articles for other diseases; (iv) studies using other drugs; (v) review articles. From all eligible studies, the following data including the first author's name, year of publication, number of patients, patients' ages and sex, type of disease, intravesical perfusions products, frequency, and duration of follow-up after treatment were extracted.

\section{Methodological Quality Assessment}

For randomized controlled trial (RCT) studies, two reviewers independently assessed the methodological quality of the eligible studies from the following six domains according to the "Cochrane Handbook 5.2.0" quality criteria: (i) random sequence generation; (ii) allocation concealment; (iii) blinding of patients and doctors; (iv) incomplete outcome data; (v) selective reporting; (vi) other biases (17). Any disagreements were resolved by consensus or judged by a third party. The Risk of Bias in Non-randomized Studies - of Interventions (ROBINS-I) assessment tool were performed to assess the self-controlled studies using the following domains: (i) bias due to confounding, bias in selection of participants into the study; (ii) bias in classification of interventions; (iii) bias due to deviations from intended interventions, (iv) bias due to missing data; (v) bias in measurement of outcomes; (vi) bias in selection of the reported result (18). The risk of bias was categorized as "Low risk", "Moderate risk", and "High Risk" of bias.

\section{Statistical Analysis}

To perform the network meta-analysis, all data was analyzed with the Review Manager statistical software version 5.0 (Nordic Cochrane Centre, Copenhagen, Denmark) and R software (version 4.0.4). A meta-analysis of commonly used numerical data was used to combine the data. Mean difference (MD) and 


\section{Table 1. Search Strategy Used in PubMed.}

\begin{tabular}{lll}
\hline Database & \multicolumn{2}{c}{ Search Strategy } \\
\hline PubMed & $\# 1$ & Hyaluronic acid OR chondroitin sulfate \\
\cline { 2 - 3 } & $\# 2$ & Interstitial cystitis OR bladder pain syndrome OR painful bladder syndrome \\
\cline { 2 - 3 } & $\# 3$ & $\# 1$ AND \#2 \\
\hline
\end{tabular}

95\% confidence interval (CI) were used as the effect parameter of the model, in which MD was used to combine the results of multiple studies. Sensitivity, heterogeneity and subgroup analysis were conducted to assess the heterogeneity of eligible studies and the impact of each study on the combined effect. The Higgins $\left(\mathrm{I}^{2}\right)$ index and $\mathrm{P}$ value were used to evaluate the effect of indicators. $\mathrm{I}^{2}$ over $25 \%, 50 \%$ and $75 \%$ indicate low, moderate and high heterogeneity between studies, respectively. It is generally believed that $\mathrm{I}^{2} \geq 50 \%$ indicates substantial heterogeneity. In our study, if $\mathrm{I}^{2}<50 \%$ and $\mathrm{P}>0.05$, it is considered that there is no significant heterogeneity and the fixed effects model is selected; otherwise, the random effects model is used for analysis, and the factors that may lead to heterogeneity are analyzed by subgroup analysis. For assessment of the publication bias, the Begg rank correlation test and Egger linear regression test were performed to assess the presence of study effects in the meta-analysis. The results were considered statistically significant when the $\mathrm{P}$ value was smaller than 0.05 .

\section{Results Characteristics of Included Studies}

A total of 311 articles were identified by searching the databases. In the primary selection process, 253 articles were excluded based on the following criteria: no or insufficient information, non-original articles, studies with animal or cell lines, studies of other diseases rather than IC/BPS, studies with other drugs, or review articles. In addition, 45 articles were excluded in the further evaluation of eligibility due to insufficient or no information, other similar diseases that were not IC/BPS, studies with other methods, or duplication. 3 RCTs (19-21) and 9 self-controlled studies (22-30) were ultimately selected. Among them, M. Özkidik et al. (22) reported the perfusion results of HA, CS, and the combination of HA and CS, and Arslan B et al. (23) reported the results of CS and their combination. Finally, 16 studies were included. A detailed flowchart showing the selection process is shown in Figure 1, and the detailed information of 16 studies used in the present study is shown in Table 2 . The patient's response to treatment was assessed through some parameters including VAS, ICSI and ICPI. The overall response rate of the treatment was $91.24 \%$.

\section{The Methodological Quality of Included Stud- ies \\ RCTs}

A quality assessment was started by measuring clinical improvement in pain, frequency, urgency, and bladder capacity of storage symptoms. Three studies were RCTs. A summary graph of bias risks for 3 studies using "Cochrane Handbook 5.2.0" quality criteria is shown in Figure 2. This study has a high risk of bias concerning the randomization of participants and personnel. The included 13 studies were self-controlled studies, and were assessed using the Non-randomized Studies - of Interventions assessment tool. The methodological quality results are shown in Figure 3. Three RCTs was assessed as high risk, and self-controlled studies were low risk.

\section{Primary and Secondary Outcomes RCTs}

Heterogeneity test showed that fixed effect model was used $(\mathrm{P}=$ $\left.0.6, \mathrm{I}^{2}=0 \%\right)$. VAS improvement from 3 included RCTs was (MD -0.57 (95\%CI -1.55, -0.41)), no statistical significance was found $(\mathrm{Z}=1.15, \mathrm{P}=0.25)$ (Figure 4).

\section{Self-Controlled Studies}

Thirteen self-controlled studies were included. A significant improvement on VAS with random-effect models from 13 included studies was found (MD -2.78 (95\% CI -3.48, -2.07)) (Figure 5A). Included studies showed significant heterogeneity $\left(\mathrm{I}^{2}=94 \%, \mathrm{P}<0.01\right)$ (Figure 1). Significant improvements were found in ICSI (MD -4.59, 95\% CI -5,62, -3.56) and ICPI (MD $-4.06,95 \%$ CI -4.93, -3.17) (Figure 5B, Figure 5C). Frequency and urgency data showed a significant improvement after IC/BPS was treated with HA/CS (frequency: MD -2.65, 95\% CI -3.35, -1.94; urgency: MD -1.86, 95\% CI -2.73, -1.00) (Figure 5D, Figure 5E); Bladder capacity restoration was better after HA/CS treatment compared to before treatment (MD 25.02, 95\% CI 19.44, 30.61) (Figure 5F).

\section{Sensitivity and Subgroup Analysis}

Sensitivity analysis showed no single study had a significant effect on the pooled VAS, and the MD range of the VAS was -2.93 to -2.64 (Figure 6). Subgroup analysis was performed to evaluate if the different drugs and follow-up times after treatment could impact the treatment of IC/BPS. Of the trials included, the subgroup analysis of 6 studies reported IC/BPS infused with HA $(22,24,25,29,31,32), 3$ IC/BPS infused with CS $(22,23,27)$, and 4 IC/BPS infused with HA/CS $(22,23,26$, 28). The changes of MD on VAS improvement were $-2.11(95 \%$ CI $-2.97,-1.26),-1.27$ (95\% CI -2.02, -0.52), and -2.16 (95\% CI $-3.48,-0.85)$ in pure HA, CS and a combination of HA and CS subgroups respectively, and the total effect test showed significant difference between the three treatments $(\mathrm{Z}=7.71, \mathrm{P}<0.01)$ (Figure 8A). Also, different follow-up times after treatment showed significant difference $(\mathrm{Z}=7.69, \mathrm{P}<0.01)$ (Figure 8A). 


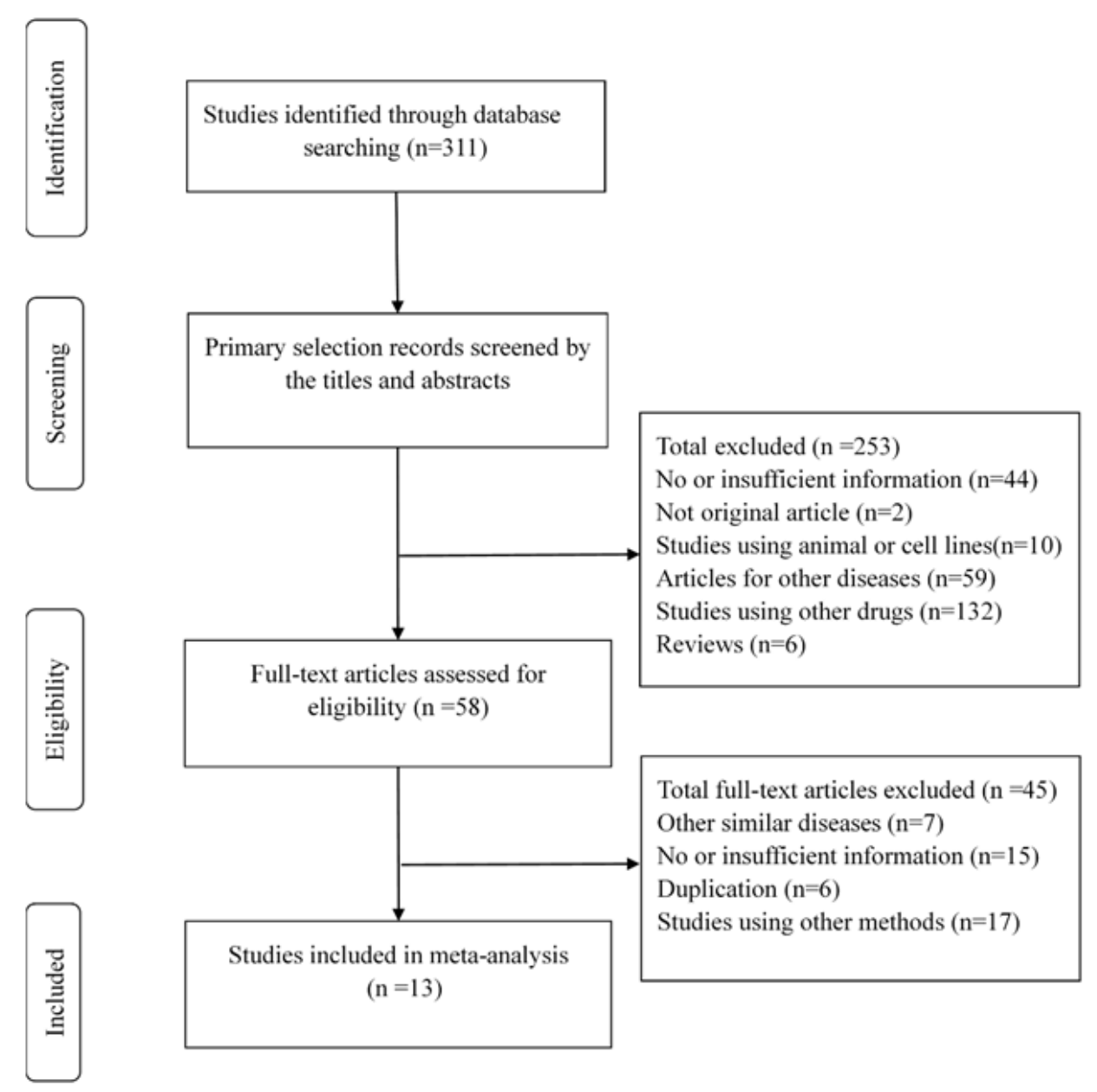

Figure 1. PRISMA Follow Diagram of the Research.

\section{Publication Bias}

Begg rank correlation test and Egger linear regression test were used to detect publication bias. The results of different outcomes are showed in Table 3.

\section{Discussion}

IC/BPS is a chronic bladder disorder characterized by bladder pain, urinary frequency, urgency, and nocturia. The mechanism of IC/BPS is not completely understood, but it proposed to involve a defective urothelim of bladder, mast cell infiltration and neurogenic inflammation (32-34). The main goals of IC/BPS treatment are to restore bladder function, prevent recurrence, and improve the quality of life (35). There are numerous treatments for IC/BPS, including dietary modification, lifestyle interventions/behavioural therapies, oral medications, intravesical perfusion, and interventional/operative therapies (15, 36). Among these treatments, it has been reported that intravesical perfusion is considered the relatively better treatment technique. It is a procedure whereby the drug is spread directly on the inner surface of the bladder to increase its local concentration and active time while reducing systemic side effects (35).
As a permeability barrier, the urothelial GAG layer plays a major role in preventing penetration of urinary toxins and pathogens into the bladder wall, and distruption of GAG layer contributes to the development of IC/BPS (37). HA and CS are natural glycoproteins in the GAG layer of the urinary bladder wall, so intravesical perfusion of HA and CS can promote the regeneration of GAG, and restore the protective barrier function of the bladder (38). HA and CS perfusion is one of main therapies for the treatment of IC/BPS. Many studies have evaluated the effectiveness of intravesical perfusion of CS and HA alone or in combination on IC/BPS $(19,22,24)$. Cervigni M. et al reported the combination of CS $(2.0 \% \mathrm{w} / \mathrm{v})$ and $\mathrm{HA}(1.6 \% \mathrm{~W} / \mathrm{V})$ caused a significant improvement in urinary symptoms following therapy (39).

There is a published meta-analysis on the effect of HA/CS on IC/BPS. Pyo et al. carried out systematic review which suggested that intravesical perfusion of $\mathrm{HA}$ alone or in combination with CS could improve a range of bladder symptoms (40). The outcomes of intravesical perfusion treatment on IC/BPS in the included studies in this review were generally followed-up for 6 months. According to our previous investigation, a number of 

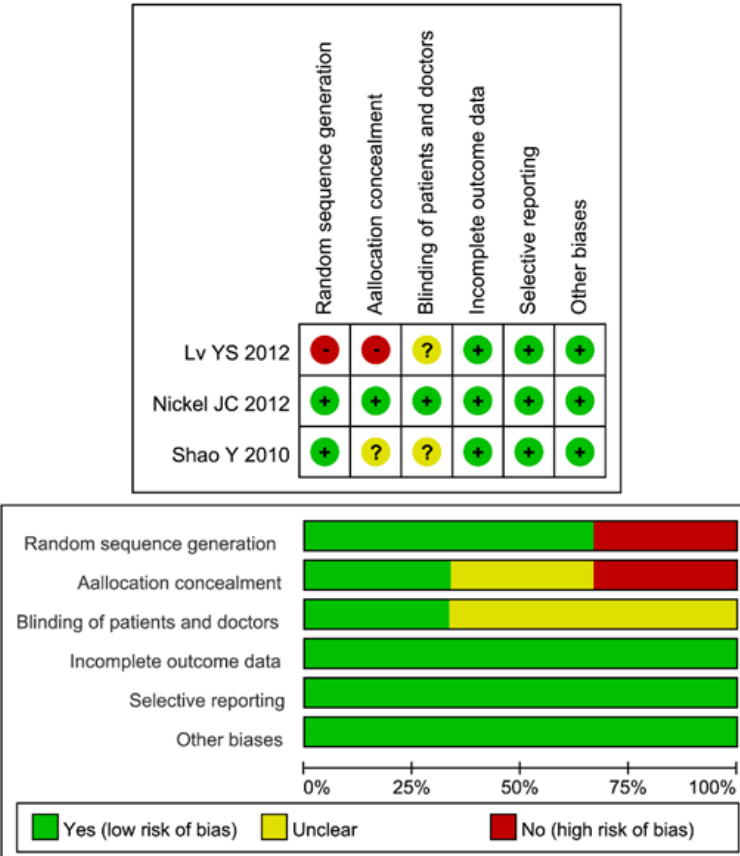

Figure 2. Randomized Clinical Trial Quality Assessment of Included Study Using The "Cochrane Handbook 5.2.0" Quality Criteria in the Meta-Analysis: Risk of Bias Graph and Summary.
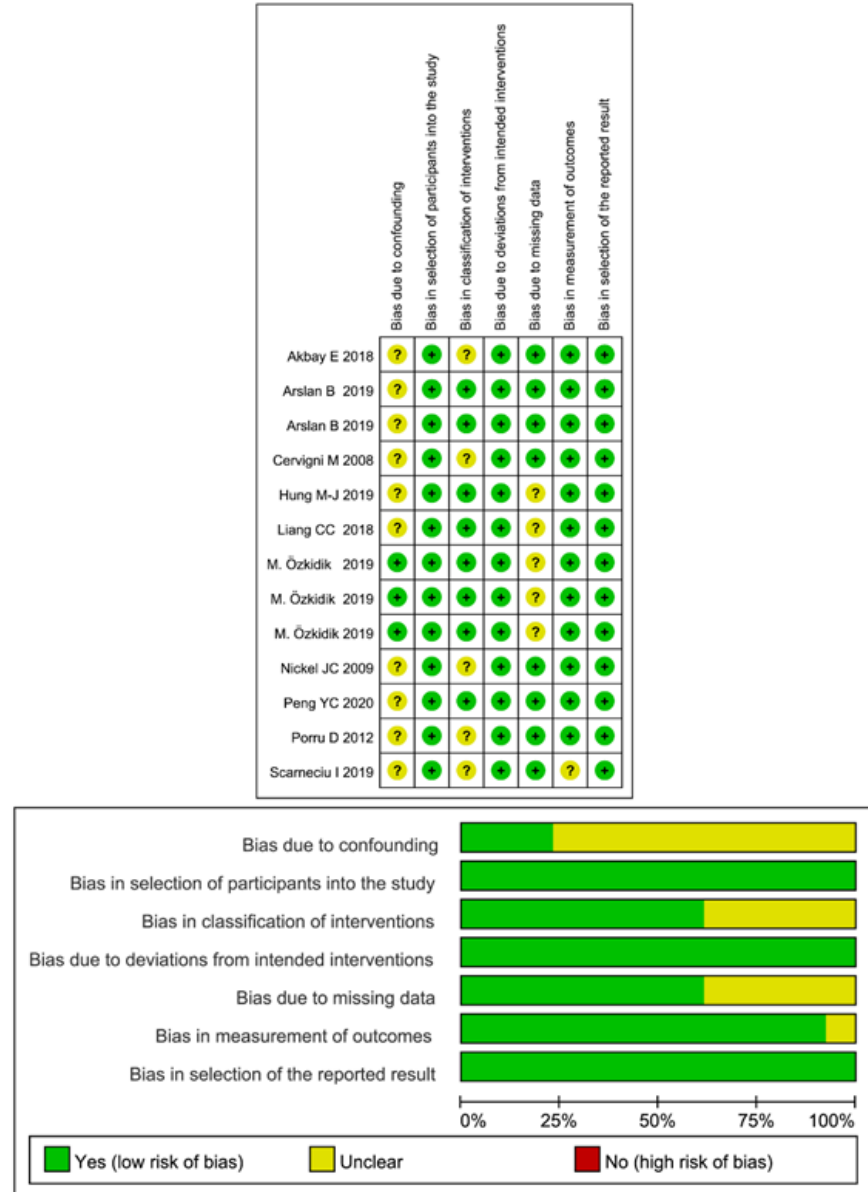

Figure 3. Randomized Clinical Trial Quality Assessment of Included Study Using the Non-Randomized Studies - Of Interventions Assessment Tool in the Meta-Analysis: Risk of Bias Graph and Summary. 


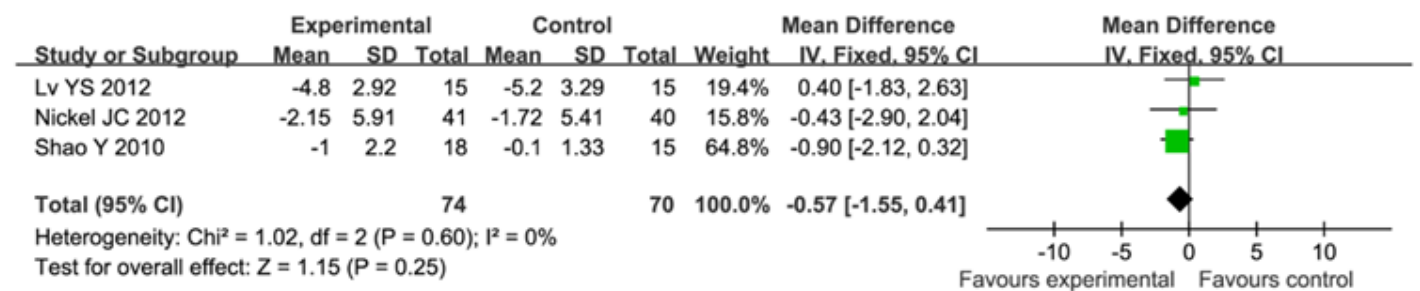

Figure 4. VAS Improvement in IC/BPS: A Meta-Analysis of Randomized Controlled Studies.

VAS: Visual Analogue Scale for Pain Symptom; IC/BPS: Interstitial Cystitis/ Bladder Pain Syndrome.

Table 2. Characteristics and Results on Intravesical Hyaluronic Acid (HA), Chondroitin Sulfate (CS), and Combination of both (HA/CS) for Interstitial Cystitis/Painful Bladder Syndrome.

\begin{tabular}{|c|c|c|c|c|c|c|c|c|}
\hline Study & Design & Disease & Pt.\# & $\operatorname{Sex}(M / F)$ & Age & Intervention & Frequency & MFU \\
\hline \multirow[t]{2}{*}{$\begin{array}{l}\text { Arslan B } \\
(2019)(23)\end{array}$} & \multirow[t]{2}{*}{ SC } & \multirow[t]{2}{*}{ IC/BPS } & 28 & $0 / 28$ & $32(19-54)$ & $\begin{array}{l}\text { CS (40 ml/80 mg) (Gepan } \\
\text { Instill) }\end{array}$ & \multirow{2}{*}{$\begin{array}{l}\text { Perfusions weekly for the } \\
\text { first month, biweekly for the } \\
\text { second month, and } \\
\text { monthly in the third and } \\
\text { fourth months }\end{array}$} & \multirow[t]{2}{*}{$\begin{array}{l}2.0 \\
\text { mo }\end{array}$} \\
\hline & & & 33 & $0 / 33$ & $35(21-52)$ & $\begin{array}{l}\text { HA }(1.6 \%, 800 \mathrm{mg} / 50 \mathrm{ml}) \text { and } \\
\text { CS }(2 \%, 1 \mathrm{~g} / 50 \mathrm{ml}) \\
\text { (iAluRil,Aspire Pharma, UK) }\end{array}$ & & \\
\hline $\begin{array}{l}\text { Liang CC } \\
(2018)(31)\end{array}$ & $\mathrm{SC}$ & IC/BPS & 30 & $0 / 30$ & $44.1(21-80)$ & $\begin{array}{l}40 \mathrm{mg} / 50 \mathrm{~mL} \text { of HA solution } \\
\text { (Cystistat@, Bioniche Teo., } \\
\text { Inverin, Co. Galway, Ireland) }\end{array}$ & $\begin{array}{l}\text { Perfusions weekly for } 4 \\
\text { weeks, then monthly for } 5 \\
\text { months. }\end{array}$ & $\begin{array}{l}3.0 \\
\text { mo }\end{array}$ \\
\hline $\begin{array}{l}\text { Porru D } \\
\text { (2012) (26) }\end{array}$ & $\mathrm{SC}$ & IC/BPS & 22 & $0 / 22$ & $46.6(23-60)$ & $\begin{array}{l}40 \mathrm{~mL} \text { of } \mathrm{HA} 1.6 \% \text { and } \mathrm{CS} \\
2.0 \% \text { in } 0.9 \% \text { saline solution } \\
\text { (IALURIL } \Theta \text {, IBSA) }\end{array}$ & $\begin{array}{l}\text { Perfusions weekly for } 8 \\
\text { weeks, then once every } 2 \\
\text { weeks for the next } 6 \\
\text { months. }\end{array}$ & $\begin{array}{l}0 \\
\text { mo }\end{array}$ \\
\hline $\begin{array}{l}\text { Akbay E } \\
(2018)(25)\end{array}$ & SC & IC/BPS & 54 & $0 / 54$ & $55(18-87)$ & HA120 mg/50 mL (Hyacyst@) & $\begin{array}{l}\text { Weekly perfusion for } 6 \\
\text { weeks. }\end{array}$ & $\begin{array}{l}3.0 \\
\text { mo }\end{array}$ \\
\hline $\begin{array}{l}\text { Nickel } \\
\text { JC(2009)(27) }\end{array}$ & SC & IC/BPS & 53 & $0 / 53$ & $44.1(21-80)$ & $20 \mathrm{~mL}$ of CS $2.0 \%$ (Uracyst ${ }^{\circledR}$ ) & $\begin{array}{l}\text { Perfusion weekly for } 6 \\
\text { weeks and then monthly for } \\
4 \text { months }\end{array}$ & $\begin{array}{l}0 \\
\text { mo }\end{array}$ \\
\hline $\begin{array}{l}\text { Nickel JC } \\
\text { (2012) (19) }\end{array}$ & RCT & IC/BPS & 49 & $0 / 49$ & $\mathrm{~N} / \mathrm{A}$ & $20 \mathrm{~mL}$ of $2 \% \mathrm{CS}$ & $\begin{array}{l}\text { Weekly perfusion for } 7 \\
\text { weeks ( } 8 \text { treatments in } \\
\text { total) }\end{array}$ & $\begin{array}{l}1.5 \\
\text { mo }\end{array}$ \\
\hline $\begin{array}{l}\text { Cervigni M } \\
(2008)(28)\end{array}$ & $\mathrm{SC}$ & IC/BPS & 23 & $0 / 23$ & $46.68(20-65)$ & $\begin{array}{l}\text { HA (high molecular weight) } \\
1.6 \% \text { and CS } 2.0 \%\end{array}$ & $\begin{array}{l}\text { Weekly perfusion for } 20 \\
\text { weeks, then monthly for } 3 \\
\text { months }\end{array}$ & $\begin{array}{l}5.0 \\
\text { mo }\end{array}$ \\
\hline $\begin{array}{l}\text { Hung M-J } \\
\text { (2019) (24) }\end{array}$ & SC & IC/BPS & 110 & $0 / 110$ & $43.6 \pm 11.8$ & $\begin{array}{l}\text { HA (Cystistat } \AA \text {, Mylan Institu- } \\
\text { tional, Galway, Ireland) }\end{array}$ & $\begin{array}{l}\text { Weekly perfusion for } 6 \\
\text { weeks, then followed by } 6 \\
\text { months perfusion }\end{array}$ & $\begin{array}{l}0 \\
\text { mo }\end{array}$ \\
\hline \multirow{3}{*}{$\begin{array}{l}\text { Özkidik M } \\
\text { (2019) (22) }\end{array}$} & \multirow[t]{3}{*}{ SC } & \multirow[t]{3}{*}{ BPS } & 24 & $20 / 4$ & 37.1 & $\mathrm{HA}(50 \mathrm{ml} / 120 \mathrm{mg})$ & \multirow{3}{*}{$\begin{array}{l}\text { Weekly perfusion for } 6 \\
\text { weeks, twice a month for } 6 \\
\text { months, then continued } \\
\text { once a month until } 24 \text { th } \\
\text { month. }\end{array}$} & \multirow{3}{*}{$\begin{array}{l}0 \\
\text { mo }\end{array}$} \\
\hline & & & 24 & $21 / 3$ & 37.4 & $\mathrm{CS}(40 \mathrm{ml} / 80 \mathrm{mg})$ & & \\
\hline & & & 24 & $21 / 3$ & 37.2 & HA/CS(half dose of each) & & \\
\hline $\begin{array}{l}\text { Lv YS } \\
\text { (2012) (20) }\end{array}$ & RCT & IC/BPS & 16 & $0 / 16$ & $41(24-66)$ & $\begin{array}{l}40 \mathrm{mg} \mathrm{HA}, 10 \mathrm{ml} \text { of } 2 \% \\
\text { lidocaine and } 8.4 \% \text { sodium } \\
\text { bicarbonate (Bioniche, Can- } \\
\text { ada). }\end{array}$ & $\begin{array}{l}\text { weekly perfusion for } 8 \\
\text { weeks and then monthly for } \\
4 \text { months with a subse- } \\
\text { quent follow-up of } 24 \\
\text { weeks }\end{array}$ & $\begin{array}{l}6.0 \\
\text { mo }\end{array}$ \\
\hline $\begin{array}{l}\text { Shao Y } \\
(2010)(21)\end{array}$ & RCT & IC & 20 & $0 / 20$ & $55(27-76)$ & $\begin{array}{l}40 \mathrm{mg} \mathrm{HA}, 10 \mathrm{ml} \text { of } 2 \% \\
\text { lidocaine and } 8.4 \% \text { sodium } \\
\text { bicarbonate (Bioniche, Can- } \\
\text { ada). }\end{array}$ & $\begin{array}{l}\text { Perfusion weekly in the first } \\
\text { month and then monthly in } \\
\text { the following } 2 \text { months }\end{array}$ & $\begin{array}{l}6.0 \\
\text { mo }\end{array}$ \\
\hline $\begin{array}{l}\text { Scarneciu I } \\
\text { (2019) (30) }\end{array}$ & SC & IC/BPS & 24 & $0 / 24$ & $52 \pm 4.74$ & $\begin{array}{l}40 \mathrm{mg} / 50 \mathrm{~mL} \text { HA solution } \\
\text { (Cystistat). }\end{array}$ & $\begin{array}{l}\text { Perfusion weekly for } 4 \\
\text { weeks, then continued } \\
\text { once every month }(21.9 \pm \\
8.79 \text { weeks). }\end{array}$ & $\begin{array}{l}10.0 \\
\text { mo }\end{array}$ \\
\hline $\begin{array}{l}\text { Peng YC } \\
(2020)(29)\end{array}$ & SC & IC/BPS & 33 & $\mathrm{~N} / \mathrm{A}$ & $46.6 \pm 7.2$ & $\begin{array}{l}40 \mathrm{mg} / 50 \mathrm{~mL} \text { HA solution } \\
\text { (Cystistat). }\end{array}$ & $\begin{array}{l}\text { Perfusion weekly for } 4 \\
\text { weeks, then monthly for } 5 \\
\text { months. }\end{array}$ & $\begin{array}{l}3.0 \\
\text { mo }\end{array}$ \\
\hline
\end{tabular}

SC: Self-controlled; RCT: Random controlled trail; Pt.: Patient; HA: Hyaluronic Acid; CS: Chondroitin Sulfate; IC: Interstitial Cystitis; BPS: Bladder Painful Syndrome; N/A: Not Available; MFU: Mean Follow Up Times from Last Perfusion; mo: Months; M/F: Male/Female. 


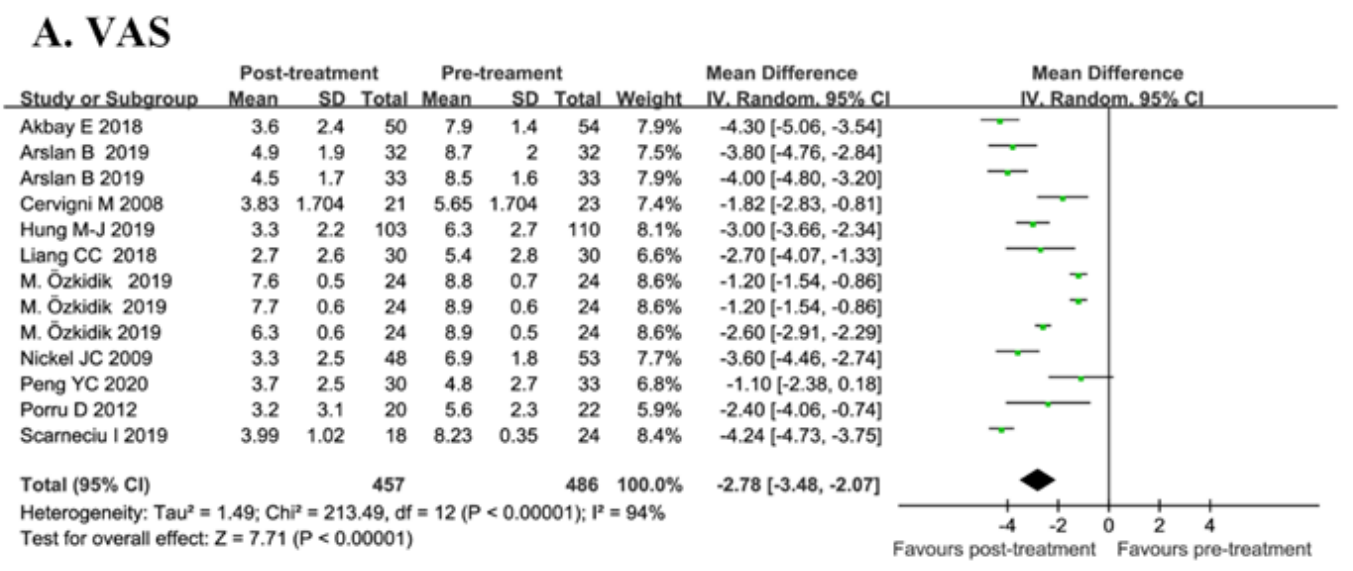

\section{B. ICSI}

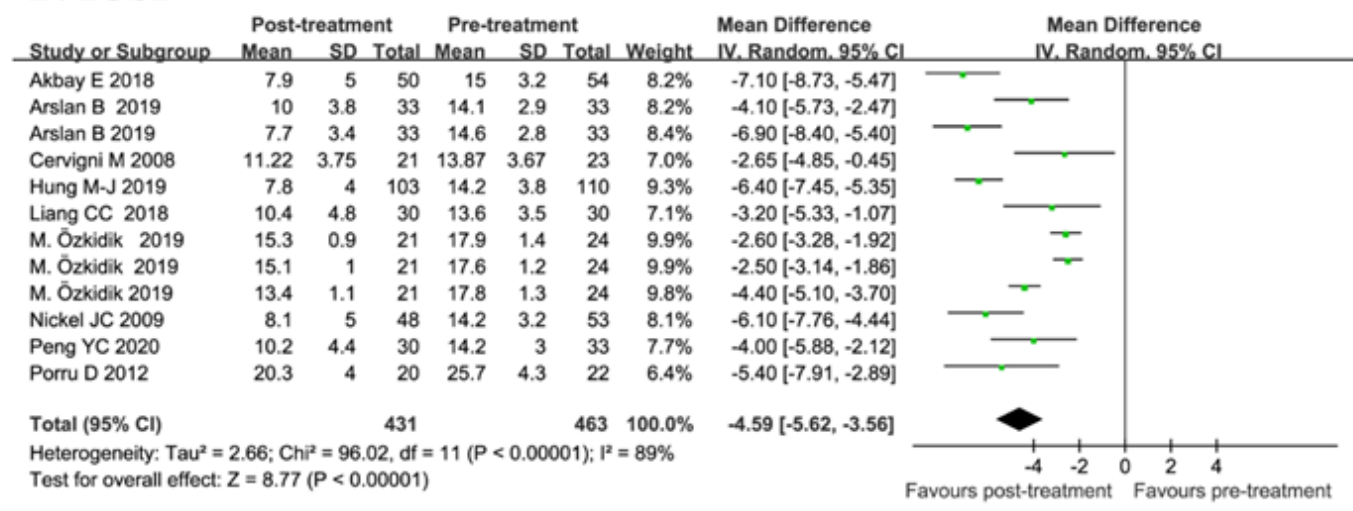

\section{ICPI}

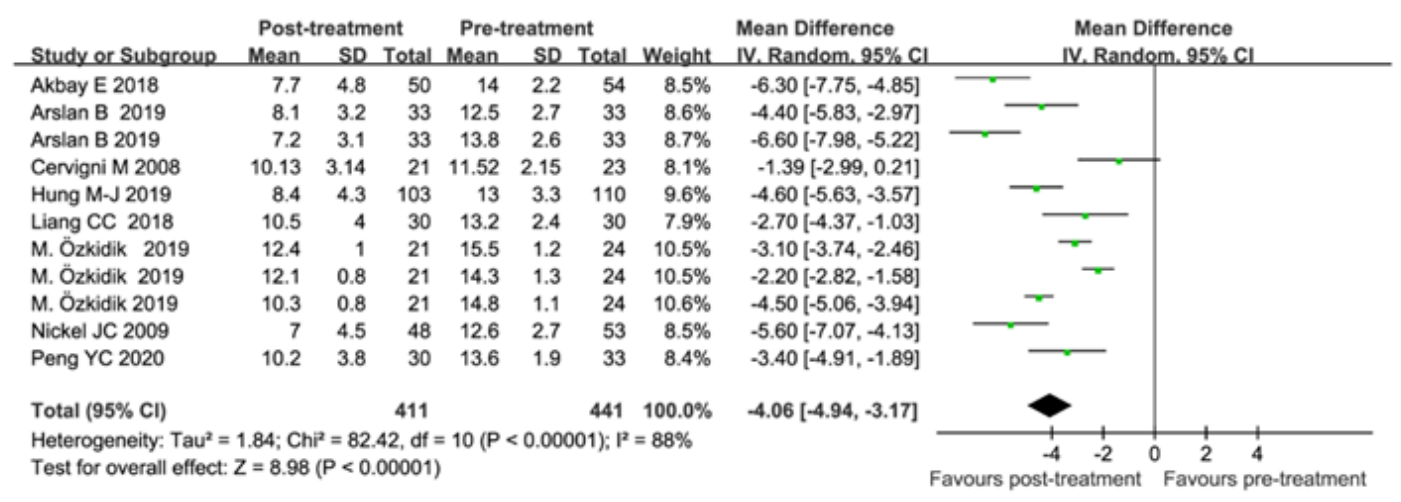

\section{Frequency}

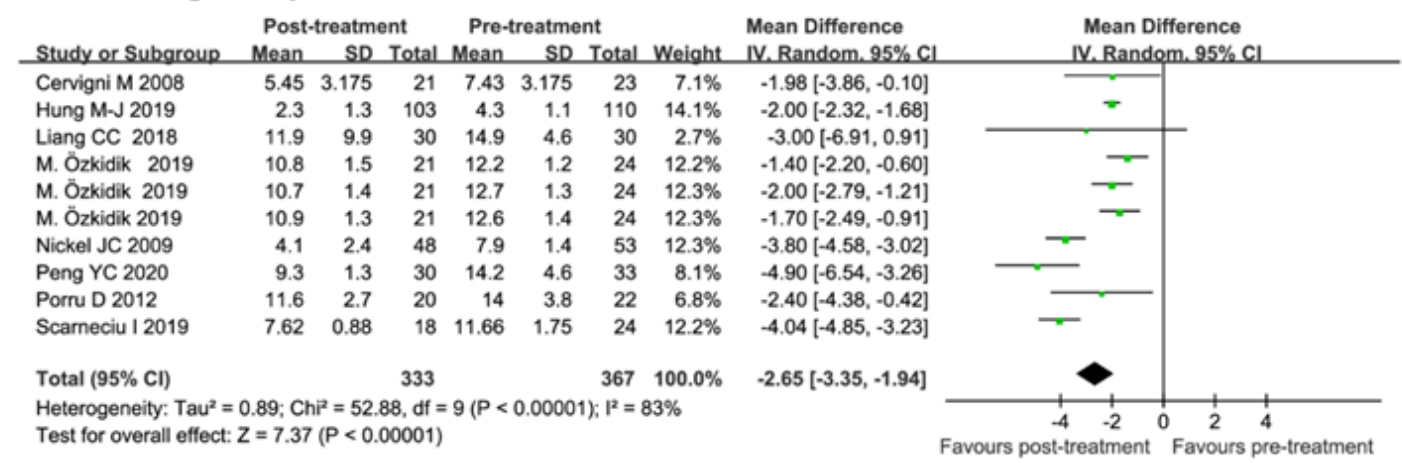

Figure 5. VAS, ICSI, ICPI, Frequency, Urgency, and Bladder Capacity Improvement in IC/BPS: A Meta-Analysis of Self-Controlled Studies.

VAS: Visual Analogue Scale For Pain Symptom, ICSI: O'Leary-Sant Interstitial Cystitis Symptom Index (ICSI), ICPI: Problem Index (ICPI), IC/BPS: Interstitial Cystitis/ Bladder Pain Syndrome. (Continued with Next Page) 


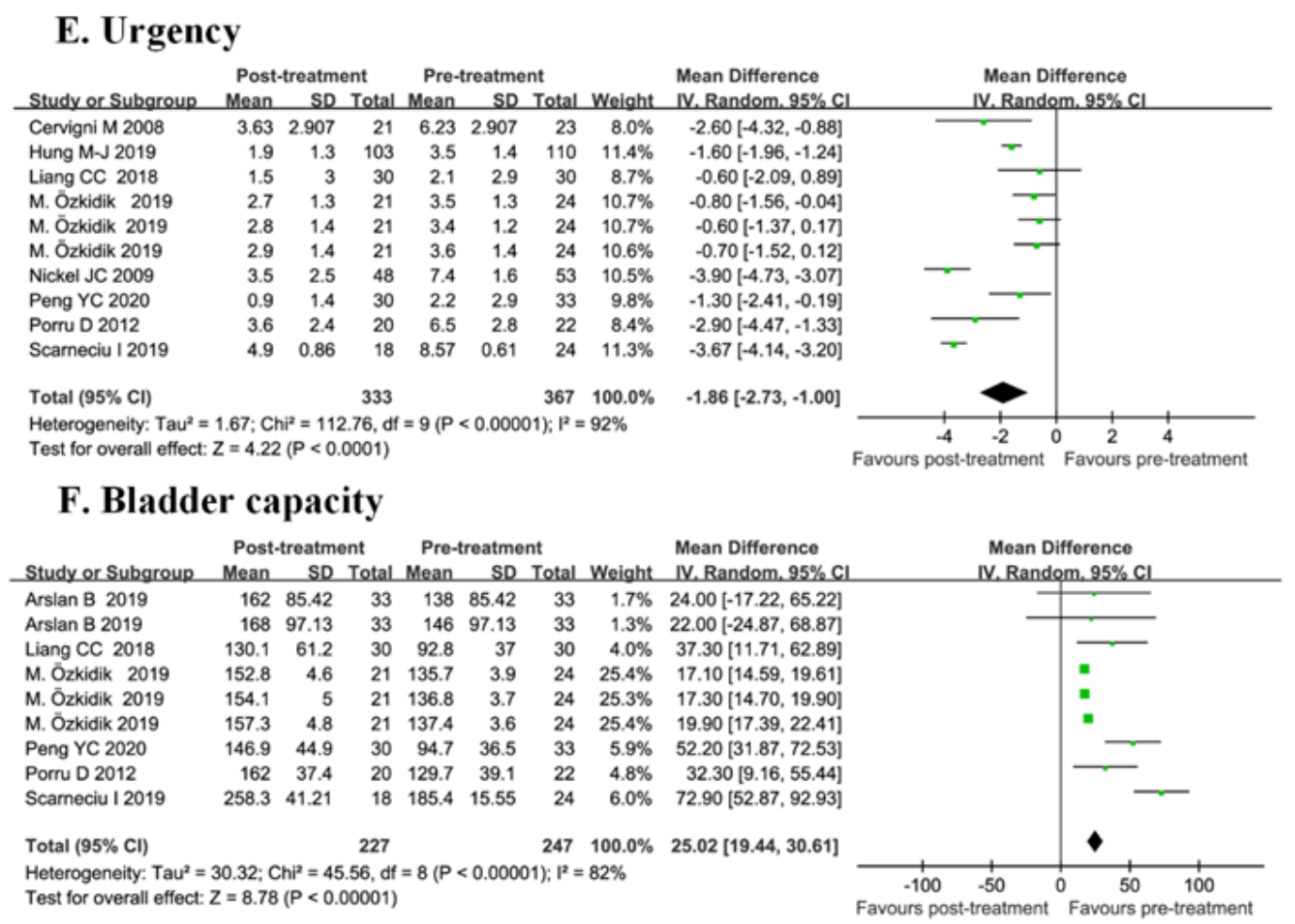

Figure 5. VAS, ICSI, ICPI, Frequency, Urgency, and Bladder Capacity Improvement in IC/BPS: A Meta-Analysis of Self-Controlled Studies. (Continued)

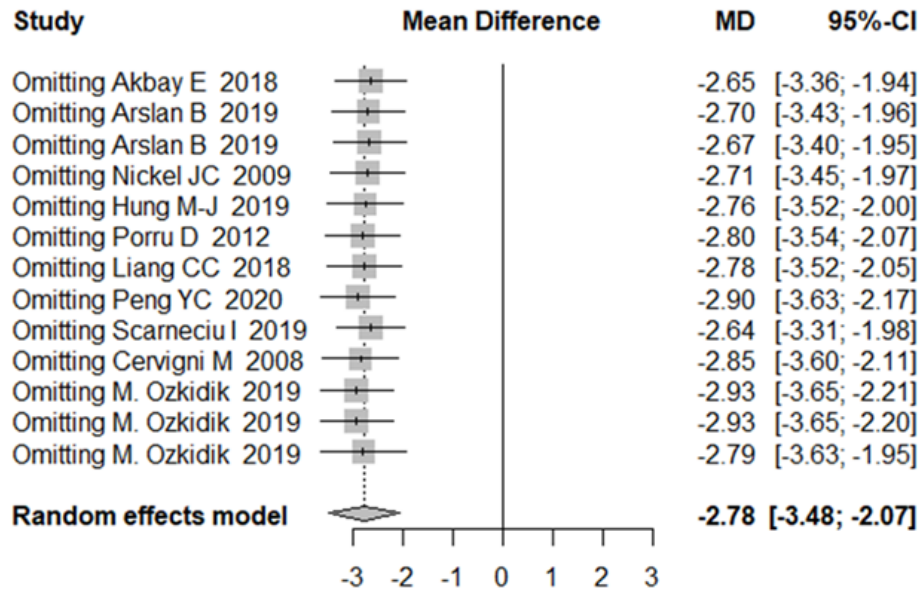

Figure 6. Sensitivity Analysis in VAS of IC/BPS.

VAS: Visual Analogue Scale For Pain Symptom, IC/BPS: Interstitial Cystitis/ Bladder Pain Syndrome

Table 3. Summary of Publication Bias.

\begin{tabular}{lll}
\hline Outcomes & Begg Rank Correlation Test & Egger Linear Regression Test \\
\hline VAS & $\mathrm{t}=-1.43, \mathrm{P}=0.1813$ & $\mathrm{z}=0.37, \mathrm{P}=0.7143$ \\
\hline ICSI & $\mathrm{t}=-1.78, \mathrm{P}=0.1055$ & $\mathrm{z}=0.41, \mathrm{P}=0.6808$ \\
\hline $\mathrm{ICPI}$ & $\mathrm{t}=-0.90, \mathrm{P}=0.3925$ & $\mathrm{z}=0.54, \mathrm{P}=0.5858$ \\
\hline Frequency & $\mathrm{t}=-1.07, \mathrm{P}=0.3179$ & $\mathrm{z}=-1.16, \mathrm{P}=0.2449$ \\
\hline Urgency & $\mathrm{t}=0.40, \mathrm{P}=0.6988$ & $\mathrm{z}=-0.80, \mathrm{P}=0.4208$ \\
\hline VAS: Visual Analogue Scale For Pain Symptom, ICSI: O'Leary-Sant Interstitial Cystitis Symptom Index (ICSI), ICPI: Problem Index (ICPI) \\
\hline
\end{tabular}




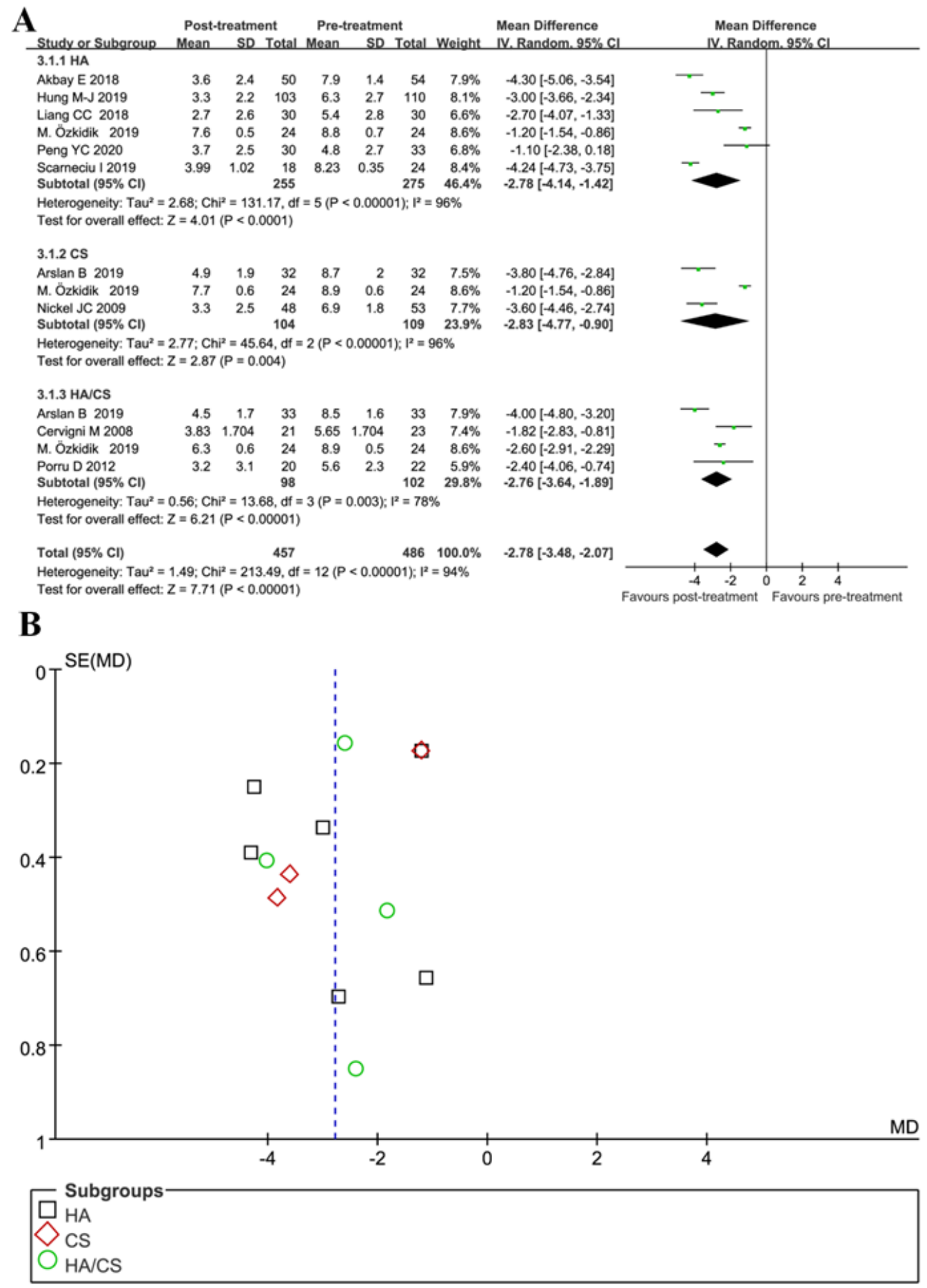

\section{Figure 7. Forest Plot Diagram (A) and Funnel Plot (B) for Subgroup Analysis of Different Drug Thera- py. \\ HA: Hyaluronic acid; CS: Chondroitin sulfate.}

studies have reported exploring the changes that affect the final treatment effect from the perspective of different follow-up times, and many studies have suggested that different follow-up times had a remarkable curative effect regarding the IC/BPS outcome change $(19,23,26)$. Erdem Akbay et al. reported the mean VAS decreased from a pretreatment level of 7.9 to 3.6 after 3-months treatment $(55 \%$ decrease, $\mathrm{P}<0.05)$, and there was also a significant correlation between the decline of ICSI and ICPI total scores (25). Kallestrup et al. reported a $40 \%$ decrease in nocturia, $30 \%$ decrease in bladder pain, $48.3 \%$ de- 
A

Post-treatment Pre-treatment Mean Difference

Mean Difference

Study er Subgroup Mean SD Total Mean SD Tetal Weight IV. Random. $95 \% \mathrm{Cl} \quad$ IV. Randem. $95 \% \mathrm{Cl}$

Hung M-J 2019

M. Özkidik 2019

M. Özkidik 2019

M. Özkidik 2019

Nickel JC 2009

Porru D 2012

Subtotal $(95 \% \mathrm{Cl})$

$\begin{array}{rrrrrrr}3.3 & 2.2 & 103 & 6.3 & 2.7 & 110 & 8.1 \% \\ 7.6 & 0.5 & 24 & 8.8 & 0.7 & 24 & 8.6 \%\end{array}$

$\begin{array}{llllllll}7.7 & 0.6 & 24 & 8.9 & 0.6 & 24 & 8.6 \% & -1.20[-1.54,-0.86\end{array}$

$\begin{array}{lllllllll}6.3 & 0.6 & 24 & 8.9 & 0.5 & 24 & 8.6 \% & -2.60[-2.91,-2.29] \\ 3.3 & 2.5 & 48 & 6.9 & 1.8 & 53 & 7.7 \% & -3.60[-4.46,-2.74]\end{array}$

$\begin{array}{llllllll}3.2 & 3.1 & 20 & 5.6 & 2.3 & 22 & 5.9 \% & -2.40[-4.06,-0.74]\end{array}$

$\begin{array}{lllll}243 & 257 & 47.4 \% & -2.28[-3.06,-1.50\end{array}$

Heterogeneity: $\operatorname{Tau}^{2}=0.82 ; \mathrm{Chi}^{2}=77.63, \mathrm{df}=5(\mathrm{P}<0.00001) ; \mathrm{I}^{2}=94 \%$

Test for overall effect: $Z=5.70(P<0.00001)$

4.2.2 2-3 months

Akbay E 2018

Arslan B 2019

Arslan B 2019

Liang CC 2018

Peng YC 2020

Subtotal $(95 \% \mathrm{Cl})$

$\begin{array}{rrrrrrr}3.6 & 2.4 & 50 & 7.9 & 1.4 & 54 & 7.9 \% \\ 4.9 & 1.9 & 32 & 8.7 & 2 & 32 & 7.5 \%\end{array}$

$\begin{array}{lllllll}4.5 & 1.7 & 33 & 8.5 & 1.6 & 33 & 7.9 \%\end{array}$

$\begin{array}{llllllll}2.7 & 2.6 & 30 & 5.4 & 2.8 & 30 & 6.6 \%\end{array}$

$\begin{array}{lllllll}3.7 & 2.5 & 30 & 4.8 & 2.7 & 33 & 6.8 \%\end{array}$

Heterogeneily: $\operatorname{Tau}^{2}=1.03 ; \mathrm{Ch}^{2}=20.59, \mathrm{df}=4(\mathrm{P}=0.0004) ; \mathrm{P}^{2}=81 \%$

Test for overall effect: $Z=6.42(P<0.00001)$

4.2.3 5-10 months

Scarneciu 12019

$\begin{array}{lllllll}3.83 & 1.62 & 21 & 5.56 & 1.62 & 23 & 7.5 \% \\ 3.99 & 1.02 & 18 & 8.23 & 0.35 & 24 & 8.4 \%\end{array}$

Scarneciu I 2019

18

$\begin{array}{lll}8.23-0.35 \quad 24 & 8.4 \%\end{array}$

$i^{2}=95 \%$

Heterogeneity: Tau $^{2}=3.00 ; \mathrm{Ch}^{2}=20.86$,

Test for overall effect: $Z=2.41(P=0.02)$

Total (95\% Cl)

457

$486 \quad 100.0 \%$

Heterogeneity: $\mathrm{Tau}^{2}=1.49 ; \mathrm{Ch}^{2}=214.04, \mathrm{~d}=$

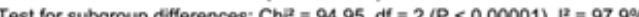

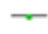

B

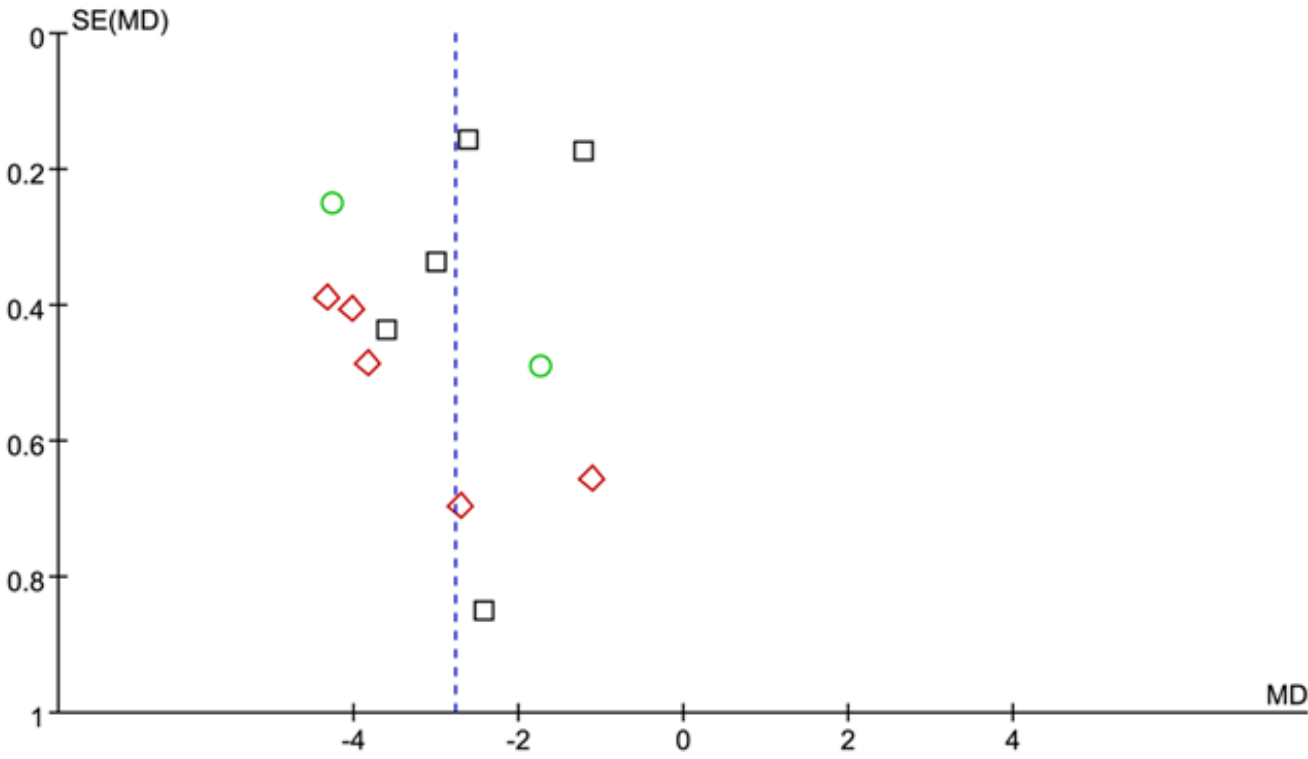

Subgroups

$\square 0$

2-3 months

5-10 months

Figure 8. Forest Plot Diagram (A) and Funnel Plot (B) for Subgroup Analysis of Different Follow-Up Time after Last Treatment.

crease in ICSI, and $50 \%$ decrease in the frequency of bladder pain and burning after 3-year treatment (41).

Subgroup analysis of VAS showed that there was significant difference between HA, CS, and the combination of HA and CS subgroups $(Z=29.97, P<0.01)$ (Figure 7). Compared with $C S$ and their combination, the perfusion of $\mathrm{HA}$ alone is more effective for the clinical treatment of IC/BPS $(\mathrm{Z}=20.51, \mathrm{P}<0.01)$

(Figure 7). The results in our present meta-analysis also showed a significant improvement in mean VAS, ICSI and ICPI, frequency, urgency, and bladder capacity of storage symptoms, 
which is consistent with the previous meta-analysis (40). Differences of outcomes may also be due to different follow-up times after last treatment. Therefore, a subgroup analysis of follow-up times after different treatments was performed in this study to obtain a more objective observation time, which has not been reported in other studies. We added further subgroup analysis and found that outcomes in the meta-analysis were followed-up from 0 to 10 months after treatment, and there was a significant outcome difference in the varied follow-up times after treatment. $(\mathrm{Z}=7.69, \mathrm{P}<0.01)$ (Figure 8).

In addition, this study was registered with PRISMA to ensure quality, since a quality assessment of the included studies is essential for the analysis of the final results. In this study, methodological quality assessment of the 3 RCTs showed high risk bias. The reason for this phenomenon is that the number of RCTs is little, and individual differences are large. However, 13 self-controlled studies were considered low risk of bias in the assessment of bias risk and methodological quality. For the assessment of publication bias, Both Begg rank correlation test and Egger linear regression test were showed no publication bias, since the $\mathrm{P}$-value is less than 0.05 .

Although we have analyzed the clinical studies performed with scientific methods, basic research to address the mechanisms of the disease is essential. Up to now, the pathogenesis of IC/BPS remains unclear. In the past few decades, it has been suggested that urea leaks could lead to chronic inflammation of the bladder, causing bladder pain or discomfort. However, visceral therapy and oral pentosan polysulfate (PPS) did not show a sustained improvement in bladder pain or frequency of urination
$(42,43)$. Smith CP. et al reported that only 69 percent of patients found improvement after botulinum toxin A (BoNTA) treatment (44). Ham et al. in their study reported that intravesical resiniferatoxin (RTX) significantly improved voiding symptoms and bladder pain of IC/BPS at 1 month of follow-up, while no favorable outcomes on voiding symptoms were seen at 3 months (45).

There are some limitations in this study: since the dosage of drug infusion was not reported in any of the included studies, subsequent studies need to evaluate whether infusion dose has any effect on the improvement of the final efficacy. In addition, in view of the fact that most of the studies included in this study are self-controlled studies and there is a lack of effective control group, it is also significant to evaluate the efficacy analysis of different types of other studies. Therefore, a well-designed RCT, large sample sizes, long term follow-up are needed to further verify the existing results.

\section{Conclusions}

In conclusion, given the various treatments mentioned above did not address the underlying inflammatory or central-sensitive pain processes in IC/BPS, HA can be a more attractive treatment option, either alone or in combination with CS. Through this meta-analysis, the included studies demonstrate that intravesical perfusion of HA or CS alone or in combination can be an advantageous treatment for the patients with IC/BPS who have failed to respond to conventional treatment. Overall, the results of this meta-analysis indicate that there is hope for patients afflicted with IC/BPS, with three helpful options available.

Author Contributions: Conceptualization, J.H., H.D., and X.X.; Methodology, X.X. and H.D.; Validation, H.D. and M.M.C.; Formal analysis, X.X. and H.D.; Investigation, M.M.C. and Z.W.G; Resources, J.H.; Data curation, Y.Z., L.C.Q. and H.D.; Writing - original draft preparation, Y.Z. and J.X.L.; Writing - review and editing, Z.W.G., C.J.Q. and Y.Z.; Visualization, J.X.L., Y.Z.L. and L.C.Q.; Supervision, J.H. and C.J.Q.; Funding acquisition, J.H. All authors have read and agreed to the published version of the manuscript.

Data Availability Statement: The data presented in this study are available on request from the corresponding author.

\section{References}

1. Lu P, Takai K, Weaver VM, Werb Z. Extracellular matrix degradation and remodeling in development and disease. Cold Spring Harbor Perspect Biol 2011; 3:a005058. DOl: https://doi.org/10.1101/cshperspect.a005058

2. Hynes RO. The extracellular matrix: Not just pretty fibrils. Science 2009; 326:1216-1219. DOI: https://doi.org/10.1126/science.1176009

3. Sasisekharan R, Shriver Z, Venkataraman G, Narayanasami U. Roles of heparan-sulphate glycosaminoglycans in cancer. Nat Rev Cancer 2002;

\section{2:521-528. DOI: https://doi.org/10.1038/nrc842}

4. Gorio A, Lesma E, Vergani L, Di Giulio AM. Glycosaminoglycan supplementation promotes nerve regeneration and muscle reinnervation. Eur $\mathrm{J}$ Neurosci 1997; 9:1748-1753. DOI: https://doi.org/10.1111/j.1460-9568.1997.tb01532.x

5. San Antonio JD, Winston BM, Tuan RS. Regulation of chondrogenesis by heparan sulfate and structurally related glycosaminoglycans. Develop Biol 1987; 123:17-24. DOI: https://doi.org/10.1016/0012-1606(87)90422-2 
6. Hurst RE. Structure, function, and pathology of proteoglycans and glycosaminoglycans in the urinary tract. World J Urol 1994; 12:3-10. DOI: https://doi.org/10.1007/bf00182044

7. Parsons CL, Stauffer C, Schmidt JD. Bladder-surface glycosaminoglycans: An efficient mechanism of environmental adaptation. Science 1980, 208:605-607. DOI: https://doi.org/10.1126/science.6154316

8. Bedini E, Parrilli M. Synthetic and semi-synthetic chondroitin sulfate oligosaccharides, polysaccharides, and glycomimetics. Carbohydrate Research 2012; 356:75-85. DOI: https://doi.org/10.1016/i.carres.2012.02.010

9. French LM, Bhambore N. Interstitial cystitis/painful bladder syndrome. Am Fam Physician 2011; 83:1175-1181

10. Clemens JQ, Link CL, Eggers PW, Kusek JW, Nyberg LM, Jr., McKinlay JB. Prevalence of painful bladder symptoms and effect on quality of life in black, Hispanic and white men and women. J Urol 2007; 177:1390-1394. DOI: https://doi.org/10.1016/j.juro.2006. 11.084

11. Jensen H, Nielsen K, Frimodt-Møller C: Interstitial cystitis: review of the literature. Urol Int 1989; 44:189-193. DOI: https://doi.org/10.1159/000281502

12. Tirumuru S, Al-Kurdi D, Latthe P. Intravesical botulinum toxin $A$ injections in the treatment of painful bladder syndrome/interstitial cystitis: A systematic review. Int Urogynecol J 2010; 21:1285-1300. DOI: https://doi.org/10.1007/s00192-010-1162-9

13. Birder L, Andersson KE. Urothelial signaling. Physiol Rev 2013; 93:653-680. DOI: https://doi.org/10.1152/physrev.00030.2012

14. Ha T, Xu JH. Interstitial cystitis intravesical therapy. Transl Androl Urol 2017; 6:S171-s179. DOI: https://doi.org/10.21037/tau.2017.06.18

15. Bschleipfer $T$, Doggweiler R, Schultz-Lampel $D$, de Jong J, Gonsior A, Hensen J, Heßdörfer E, Kaftan BT, Kuhn A, Kunzendorf U, Lampel A, Landmesser A, Loch A, Moormann O, Müller B, Neuhaus J, Reich A, Roth R, Schumacher S, Stratmeyer R, Vahlensieck W, Wördehoff A, Münder-Hensen B. Diagnostik und Therapie der interstitiellen Zystitis (IC/BPS): S2k-Leitlinie der Deutschen Gesellschaft für Urologie [Diagnosis and treatment of interstitial cystitis (IC/PBS) : S2k guideline of the German Society of Urology]. Urologe A 2019; 58(11):1313-1323. German. DOI:

https://doi.org/10.1007/s00120-019-01054-2. Erratum in: Urologe A 2019; 58(12):1498.

16. Chintea $\mathrm{CL}$, Belal $\mathrm{M}$. Is there enough evidence for the use of intravesical instillations of glycosaminoglycan analogues in interstitial cystitis? BJU Int 2013; 111:192-193. DOI: https://doi.org/10.1111/j.1464-410X.2012.11635.x

17. Higgins JP, Altman DG, Gøtzsche $P C$, Jüni $P$, Moher D, Oxman AD, Savovic J, Schulz KF, Weeks L, Sterne JA. The Cochrane Collaboration's tool for assessing risk of bias in randomised trials. BMJ 2011; 343:d5928. DOI: https://doi.org/10.1136/bmi.d5928

18. Sterne JA, Hernán MA, Reeves BC, Savović J, Berkman ND, Viswanathan M, Henry D, Altman DG,
Ansari MT, Boutron I, Carpenter JR, Chan AW, Churchill R, Deeks JJ, Hróbjartsson A, Kirkham J, Jüni P, Loke YK, Pigott TD, Ramsay CR, Regidor D, Rothstein HR, Sandhu L, Santaguida PL,

Schünemann HJ, Shea B, Shrier I, Tugwell P, Turner $\mathrm{L}$, Valentine JC, Waddington $\mathrm{H}$, Waters $\mathrm{E}$, Wells GA, Whiting PF, Higgins JP. ROBINS-I: a tool for assessing risk of bias in non-randomised studies of interventions. BMJ 2016; 355:i4919. DOI: https://doi.org/10.1136/bmj.i4919

19. Nickel JC, Hanno P, Kumar K, Thomas H. Second multicenter, randomized, double-blind, parallel-group evaluation of effectiveness and safety of intravesical sodium chondroitin sulfate compared with inactive vehicle control in subjects with interstitial cystitis/bladder pain syndrome. Urology 2012; 79:1220-1224. DOI: https://doi.org/10.1016/j.urology.2012.01.059

20. Lv YS, Zhou HL, Mao HP, Gao R, Wang YD, Xue XY. Intravesical hyaluronic acid and alkalinized lidocaine for the treatment of severe painful bladder syndrome/interstitial cystitis. Int Urogynecol J 2012; 23:1715-1720. DOI: https://doi.org/10.1007/s00192-012-1802-3

21. Shao Y, Shen ZJ, Rui WB, Zhou WL. Intravesical instillation of hyaluronic acid prolonged the effect of bladder hydrodistention in patients with severe interstitial cystitis. Urology 2010; 75:547-550. DOI: https://doi.org/10.1016/j.urology.2009.09.078

22. Özkidik M. Assessment of long-term intravesical hyaluronic acid, chondroitin sulfate and combination therapy for patients with bladder pain syndrome. Cent Eur J Urol 2019; 72:270-275. DOI: https://doi.org/10.5173/ceju.2019.0007

23. Burak Arslan 1 SG, Ersin Gökmen 2, Oktay Özman 2 , Mustafa Asım Avci 2, Enver Özdemir 2. Outcomes of intravesical chondroitin-sulfate and combined hyaluronic-acid/chondroitin-sulfate therapy on female sexual function in bladder pain syndrome. International urogynecology journal 2019. DOI: https://doi.org/10.1007/s00192-019-04036-2

24. Hung M-J, Tsai C-P, Lin Y-H, Huang W-C, Chen G-D, Shen P-S. Hyaluronic acid improves pain symptoms more than bladder storage symptoms in women with interstitial cystitis. Taiwan J Obstet Gynecol 2019; 58:417-422. DOI: https://doi.org/10.1016/j.tjog.2018.11.033

25. Akbay E, Çayan S, Kılınç C, Bozlu M, Tek M, Efesoy $O$. The short-term efficacy of intravesical instillation of hyaluronic acid treatment for bladder pain syndrome/interstitial cystitis. Turkish J Urol 2018; 45:129-134. DOI: https://doi.org/10.5152/tud.2018.35920

26. Porru D, Leva F, Parmigiani A, Barletta D, Choussos D, Gardella B, Daccò MD, Nappi RE, Allegri M, Tinelli C, Bianchi CM, Spinillo A, Rovereto B. Impact of intravesical hyaluronic acid and chondroitin sulfate on bladder pain syndrome/interstitial cystitis. Int Urogynecol J 2012; 23:1193-1199. DOI: https://doi.org/10.1007/s00192-011-1546-5

27. Nickel JC, Egerdie B, Downey J, Singh R, Skehan A, Carr L, Irvine-Bird K. A real-life multicentre clinical practice study to evaluate the efficacy and safety of 
intravesical chondroitin sulphate for the treatment of interstitial cystitis. BJU Int 2009; 103:56-60. DOI: https://doi.org/10.1111/j.1464-410X.2008.08028.x

28. Cervigni M, Natale F, Nasta L, Padoa A, Voi RL, Porru D. A combined intravesical therapy with hyaluronic acid and chondroitin for refractory painful bladder syndrome/interstitial cystitis. Int Urogynecol J 2008; 19:943-947. DOI: https://doi.org/10.1007/s00192-008-0572-4

29. Peng YC, Yueh-Hsia Chiu S, Feng M, Liang CC. The effect of intravesical hyaluronic acid therapy on urodynamic and clinical outcomes among women with interstitial cystitis/bladder pain syndrome. Taiwan J Obstet Gynecol 2020; 59:922-926. DOI: https://doi.org/10.1016/j.tjog.2020.09.021

30. Scarneciu I, Bungau S, Lupu AM, Scarneciu CC, Bratu OG, Martha O, Tit DM, Aleya L, Lupu S. Efficacy of instillation treatment with hyaluronic acid in relieving symptoms in patients with BPS/IC and uncomplicated recurrent urinary tract infections Long-term results of a multicenter study. Eur J Pharm Sci 2019; 139:105067. DOI: https://doi.org/10.1016/i.ejps.2019.105067

31. Liang $\mathrm{C}-\mathrm{C}$, Lin $\mathrm{Y}-\mathrm{H}$, Hsieh $\mathrm{W}-\mathrm{C}$, Huang L. Urinary and psychological outcomes in women with interstitial cystitis/bladder pain syndrome following hyaluronic acid treatment. Taiwanese J Obstet Gynecol 2018; 57:360-363. DOI: https://doi.org/10.1016/j.tjog.2018.04.006

32. Butrick CW, Howard FM, Sand PK. Diagnosis and treatment of interstitial cystitis/painful bladder syndrome: A review. J Womens Health (Larchmt) 2010; 19:1185-1193. DOI: https://doi.org/10.1089/jwh.2009.1702

33. Tyagi P, Barclay D, Zamora R, Yoshimura N, Peters K, Vodovotz Y, Chancellor M. Urine cytokines suggest an inflammatory response in the overactive bladder: A pilot study. Int Urol Nephrol 2010; 42:629-635. DOI: https://doi.org/10.1007/s11255-009-9647-5

34. Liu HT, Shie JH, Chen SH, Wang YS, Kuo HC. Differences in mast cell infiltration, E-cadherin, and zonula occludens- 1 expression between patients with overactive bladder and interstitial cystitis/bladder pain syndrome. Urology 2012; 80:225.e213-228. DOI: https://doi.org/10.1016/j.urology.2012.01.047

35. Zhang W, Deng X, Liu C, Wang X. Intravesical treatment for interstitial cystitis/painful bladder syndrome: A network meta-analysis. Int Urogynecol J 2017; 28:515-525. DOI: https://doi.org/10.1007/s00192-016-3079-4

36. Garzon S, Laganà AS, Casarin J, Raffaelli R, Cromi A, Sturla D, Franchi M, Ghezzi F. An update on treat- ment options for interstitial cystitis. Prz

Menopauzalny 2020; 19:35-43. DOI:

https://doi.org/10.5114/pm.2020.95334

37. Wyndaele JJJ, Riedl C, Taneja R, Lovász S, Ueda T, Cervigni M. GAG replenishment therapy for bladder pain syndrome/interstitial cystitis. Neurourol Urodyn 2019; 38:535-544. DOI: https://doi.org/10.1002/nau.23900

38. Giusto LL, Zahner PM, Shoskes DA. An evaluation of the pharmacotherapy for interstitial cystitis. Expert Opin Pharmacother 2018; 19:1097-1108. DOI: https://doi.org/10.1080/14656 566.2018.1491968

39. Cervigni M, Natale F, Nasta L, Mako A. Intravesical hyaluronic acid and chondroitin sulphate for bladder pain syndrome/interstitial cystitis: long-term treatment results. Int Urogynecol J 2012; 23:1187-1192. DOI: https://doi.org/10.1007/s00192-012-1742-y

40. Pyo JS, Cho WJ. Systematic Review and Meta-Analysis of Intravesical Hyaluronic Acid and HyaIuronic Acid/Chondroitin Sulfate Instillation for Interstitial Cystitis/Painful Bladder Syndrome. Cell Physiol Biochem 2016; 39:1618-1625. DOI: https://doi.org/10.1159/000447863

41. Kallestrup EB, Jorgensen SS, Nordling J, Hald T. Treatment of interstitial cystitis with Cystistat: A hyaluronic acid product. Scand J Urol Nephrol 2005; 39:143-147. DOI: https://doi.org/10.1080/00365590410015876-1

42. Parsons CL, Housley T, Schmidt JD, Lebow D. Treatment of interstitial cystitis with intravesical heparin. Br J Urol 1994; 73:504-507. DOI: https://doi.org/10.1111/j.1464-410x.1994.tb07634.x

43. Sant GR, Propert KJ, Hanno PM, Burks D, Culkin D, Diokno AC, Hardy C, Landis JR, Mayer R, Madigan R, Messing EM, Peters K, Theoharides TC, Warren J, Wein AJ, Steers W, Kusek JW, Nyberg LM; Interstitial Cystitis Clinical Trials Group. A pilot clinical trial of oral pentosan polysulfate and oral hydroxyzine in patients with interstitial cystitis. J Urol 2003; 170:810-815. DOI: https://doi.org/10.1097/01.ju.0000083020.06212.3d

44. Smith CP, Radziszewski P, Borkowski A, Somogyi GT, Boone TB, Chancellor MB. Botulinum toxin A has antinociceptive effects in treating interstitial cystitis. Urology 2004; 64:871-875; discussion 875. DOI: https://doi.org/10.1016/j.urology.2004.06.073

45. Ham BK, Kim JH, Oh MM, Lee JG, Bae JH. Effects of combination treatment of intravesical resiniferatoxin instillation and hydrodistention in patients with refractory painful bladder syndrome/interstitial cystitis: A pilot study. Int Neurourol J 2012; 16:41-46. DOI: https://doi.org/10.5213/inj.2012.16.1.41 